Ambiente \& Água - An Interdisciplinary Journal of Applied Science
ISSN 1980-993X - doi:10.4136/1980-993X
www.ambi-agua.net
E-mail: ambi.agua@gmail.com

\title{
Regionalization of maximum, minimum and mean streamflows for the Juruena River basin, Brazil
}

\author{
ARTICLES doi:10.4136/ambi-agua.2418
}

Received: 01 Jun. 2019; Accepted: 23 Mar. 2020

\author{
Talisson Sáteles Matos ${ }^{1}{ }^{(D}$; Eduardo Morgan Uliana ${ }^{1 *}$; \\ Camila Aparecida da Silva Martins ${ }^{2}$; Luis Miguel Castillo Rapalo ${ }^{3}$
}

\begin{abstract}
${ }^{1}$ Instituto de Ciências Agrárias e Ambientais. Universidade Federal de Mato Grosso (UFMT), Avenida Alexandre Ferronato, n 1200, Cep: 78557-267, Sinop, MT, Brazil. E-mail: talisson07@ hotmail.com ${ }^{2}$ Departamento de Engenharia Rural. Universidade Federal do Espírito Santo (UFES), Alto Universitário, S/N, CEP: 29500-000, Alegre, ES, Brazil. E-mail: camila.cca@ hotmail.com

${ }^{3}$ Programa de Pós-Graduação em Recursos Hídricos. Faculdade de Arquitetura, Engenharia e Tecnologia. Universidade Federal de Mato Grosso (UFMT), Avenida Fernando Corrêa, nº 2367, CEP: 78060-900, Cuiabá, MT, Brazil.E-mail: luis.castillo@unah.hn

${ }^{*}$ Corresponding author. E-mail: morganuliana@gmail.com
\end{abstract}

\begin{abstract}
This study aimed to regionalize maximum $\left(\mathrm{Q}_{\max }\right)$, minimum $\left(\mathrm{Q}_{95}\right)$, and long-term mean $\left(\mathrm{Q}_{\mathrm{ltm}}\right)$ streamflows in the Juruena River Basin to further water-resource planning and management, especially regarding water-use grant rights, streamflow regulation, and hydraulic designs. To do that, a traditional method was used, which relates the interest streamflows with sub-basin physiographic parameters by linear and nonlinear regressions. In summary, the traditional method was efficient for regionalization of $\mathrm{Q}_{95}, \mathrm{Q}_{\mathrm{ltm}}$, and $\mathrm{Q}_{\max }$ streamflows for the Juruena River Basin. Moreover, the explanatory variables able to provide the best results for regionalization of $\mathrm{Q}_{95}$ and $\mathrm{Q}_{\mathrm{ltm}}$ stream flows are drainage area, total watercourse length, and sub-basin mean altitude. For $\mathrm{Q}_{\max }$ regionalization, the best results were provided by explanatory variables like drainage area, perimeter, and total watercourse length.
\end{abstract}

Keywords: Amazon basin, extreme events, water availability, water resources planning and management.

\section{Regionalização de vazões máximas, mínima e média para a bacia hidrográfica do Rio Juruena, Brasil}

\section{RESUMO}

O objetivo do trabalho foi regionalizar as vazões máximas $\left(\mathrm{Q}_{\max }\right)$, mínima $\left(\mathrm{Q}_{95}\right)$ e média de longa duração $\left(\mathrm{Q}_{\mathrm{ttm}}\right)$ da bacia do rio Juruena para fins de planejamento e gestão de recursos hídricos, sobretudo no que se refere aos aspectos relacionados a outorga de direito de uso da água, regularização de vazões e dimensionamento de obras hidráulicas. Para regionalização dessas vazões foi utilizado o método tradicional o qual relaciona as vazões de interesse com as características fisiográficas das sub-bacias por meio de regressão linear e não linear. Conclui-se que: o método tradicional é eficiente para regionalização das vazões $\mathrm{Q}_{95}$, $\mathrm{Q}_{\mathrm{ltm}}$ e $\mathrm{Q}_{\max }$ na bacia do rio Juruena; as variáveis explicativas que proporcionam os melhores resultados para regionalização da vazão $\mathrm{Q}_{95}$ e $\mathrm{Q}_{\mathrm{ltm}}$ na bacia do rio Juruena são a área de drenagem, o comprimento total dos cursos de água e a altitude média das sub-bacias. Já para regionalização da $\mathrm{Q}_{\max }$ as variáveis explicativas que proporcionam os melhores resultados são a área de drenagem, perímetro e comprimento total dos cursos de água. 
Palavras-chave: bacia amazônica, disponibilidade hídrica, eventos extremos, planejamento e gestão de recursos hídricos.

\section{INTRODUCTION}

Hydrological regionalization comprises a set of tools that allow greater exploitation of available data and help to estimate hydrological variables in areas with no or limited data (Li et al., 2010; Arai et al., 2012; Beck et al., 2016; Beskow et al., 2016). In this sense, streamflows in a river basin can be estimated by several mathematical models, considering physiographic features of a catchment area. Thus, this procedure allows hydrological studies that contribute to preventive and corrective actions towards human occupation in drainage basin areas.

Among the most-used streamflow regionalization methods, there are methods that use regression equations for hydrologically homogeneous regions (Eletrobras, 1985) and a few that apply automatic interpolation and extrapolation techniques in a geographic information system (GIS) environment (Pruski et al., 2015; Cassalho et al., 2017).

Hydrological regionalization is based on the relation between the interest streamflows and the basin physiographic characteristics, obtained with regression analysis (traditional method); it is the simplest and easiest implementation method. Authors like Cecílio et al. (2018), Pruski et al. (2013), Uliana et al. (2016), Lisboa et al. (2008), Lopes et al. (2016; 2017) obtained regionalized data regarding the maximum, minimum and mean streamflows with accuracy and precision for watersheds located in different regions of brazil.

According to the literature, using data from stream-gauging stations to measure streamflows in a river basin is necessary, even if the gauging stations are located at different sites. This contributes to water-resource management in a region, since such information is used as a reference for granting water-use rights. For Beck et al. (2016), streamflow gauge network may not cover an entire hydrography; therefore, improved methods to acquire all necessary information are extremely essential.

In Mato Grosso State, there has been growing water demand for electric power generation supply, crop irrigation, as well as for industrial and human purposes. Each research raises many questions about wise management and use of the existing water resources and brings a possible resolution to local conflicts about water uses (Alves et al., 2009; Oliveira et al., 2019). In addition, there is a lack of hydrological information for the region in question, mainly for the Juruena River Basin. Therefore, it is necessary to underline the relevance and need for streamflow regionalization studies to solve problems of increasing water demand in the region.

Based on a study conducted by the Brazilian Water Agency (ANA, 2017), the Juruena River Basin is irrigated by central pivots and has the potential to increase its own irrigated area. Moreover, the basin has a high potential for installation of hydropower plants, which further demands quantification of maximum, minimum, and mean streamflows for reservoir designing and water-use granting purposes.

According to records of the Energy Research Company (EPE, 2010), along the rivers belonging to the Juruena River Basin there is a total of nine plants, among which six are small hydropower plants (SHPPs) and three hydropower-generating plants (HGPs), which together produce 93.7 MW of energy. There are five HPPs still under construction, and under concession there are seven HPPs and two HGPs.

Among the streamflow applications for water-resource engineering, the maximum $\left(\mathrm{Q}_{\max }\right)$, minimum $\left(\mathrm{Q}_{\min }\right)$ and mean $\left(\mathrm{Q}_{\mathrm{med}}\right)$ streamflows stand out in this research. The mean streamflow in a watershed allows the characterization of its own potential water availability or energetic potential; moreover, it is the biggest streamflow to be regulated in one watercourse, influencing directly water-reservoirs dimensions. Then, the minimum streamflow allows us to characterize natural water availability on a watercourse and could be considered a limitation on waterconcession rights allowing the use of water resources on Brazilian watersheds. Finally, the

Rev. Ambient. Água vol. 15 n. 3, e2418 - Taubaté 2020 
maximum streamflow associated with different return periods (Tr) is essential information for hydraulic-works sizing, like dams, bridges, manholes, drainage channels and more.

Regarding the minimum and mean streamflows, this research focused on the streamflow with $95 \%$ of permanence in time on the watercourse $\left(Q_{95}\right)$ and the long-term mean streamflow $\left(\mathrm{Q}_{\mathrm{ltm}}\right)$. The streamflow $\mathrm{Q}_{95}$ is used as reference for procedures of water concession in the Mato Grosso Estate, by state and national agencies (Brazilian Water Agency - ANA); also, these agencies are responsible for water-resource management tool implementation (Federal Law 9.433 of January 8 of 1997). Furthermore, the $Q_{1 t m}$ represents the mathematical mean from a historical streamflow series and is essential information to determine dam volume through simulation, according to the method described by Tucci and Clarke (2016).

Pruski et al. (2006) and Tucci (2009) stated that maximum, minimum, and long-term mean streamflows are used to characterize flow conditions in a watercourse. Therefore, regionalization of maximum $\left(\mathrm{Q}_{\max }\right)$, minimum with $95 \%$ permanence $\left(\mathrm{Q}_{95}\right)$, and long-term mean $\left(\mathrm{Q}_{\mathrm{ltm}}\right)$ streamflows must be performed to support studies on streamflow hydrological behavior of rivers and hence contribute to the planning and management of water resources.

In view of above, the objective of this study was to evaluate and regionalize the streamflows (maximum, minimum, and long-term mean) of the watercourses in the Juruena River Basin, northern Mato Grosso State, Brazil.

\section{MATERIALS AND METHODS}

The study was carried out in the Juruena River Basin (Figure 1), which is in the northwest region of Mato Grosso State, Brazil. It has 182,000 km² of drainage area and 4,600 km of perimeter. According to Souza et al. (2013), the region encompassing this basin presents a savannah tropical climate $(A w)$, with mean temperatures above $18^{\circ} \mathrm{C}$, in all months of the year. The dry season occurs in autumn-winter and the rainy one in spring-summer. Total annual rainfall ranges from 1,200 to $2,000 \mathrm{~mm}$, approximately.
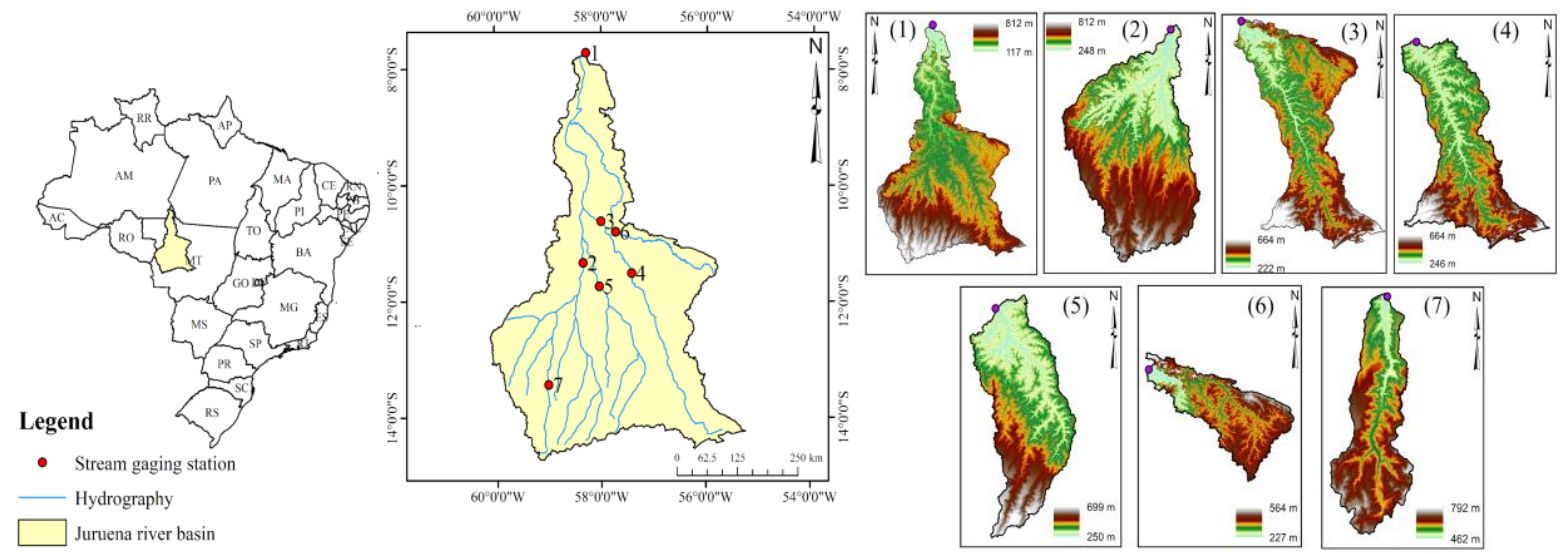

Figure 1. Map of the Juruena River Basin highlighting the location of the stream-gauging stations and the hypsometry of sub-basins.

The regionalization of maximum $\left(\mathrm{Q}_{\max }\right)$, long-term mean $\left(\mathrm{Q}_{1 \mathrm{tm}}\right)$, and minimum $\left(\mathrm{Q}_{95}\right)$ flows, associated with different return periods, were performed using historical streamflow series from seven stream-gaging stations, which are within the Juruena River Basin (Table 1). The historical series records were obtained from the database of the Hydrological Information System (http://hidroweb.ana.gov.br), which belongs to the Brazilian Water Agency (ANA).

To determine the maximum, minimum and mean streamflows, only the periods of data were considered that did not have any missing data. Table 1 shows the period of consistent data $(\mathrm{P})$ and the quantity of years without missing data $(\mathrm{N})$. 
Table 1. Code and location of the stream-gauging stations of the Juruena River Sub-basins used in the study.

\begin{tabular}{cclllccccc}
\hline ID & Code & Name & River & City & N & P & Latitude & Longitude & Ad \\
\hline 1 & 17130000 & Foz do Juruena & Juruena & Apiacás & 6 & $1986-1996$ & $-09^{\circ} 55^{\prime} 00^{\prime \prime}$ & $-58^{\circ} 17^{\prime} 00^{\prime \prime}$ & $182,458.3$ \\
2 & 17093000 & Fontanilhas & Juruena & Juína & 30 & $1978-2013$ & $-11^{\circ} 21^{\prime} 30^{\prime \prime}$ & $-58^{\circ} 20^{\prime} 34^{\prime \prime}$ & $55,924.2$ \\
3 & 17123000 & Rio Arínos & Arínos & Juara & 9 & $2000-2013$ & $-10^{\circ} 38^{\prime} 21^{\prime \prime}$ & $-58^{\circ} 00^{\prime} 15^{\prime \prime}$ & $57,110.1$ \\
4 & 17120000 & Porto dos Gaúchos & Arínos & Porto dos Gaúchos & 25 & $1973-2007$ & $-11^{\circ} 32^{\prime} 12^{\prime \prime}$ & $-57^{\circ} 25^{\prime} 25^{\prime \prime}$ & $37,069.6$ \\
5 & 17095000 & Fazenda Tombador & Rio do Sangue & Brasnorte & 21 & $1984-2013$ & $-11^{\circ} 43^{\prime} 05^{\prime \prime}$ & $-58^{\circ} 02^{\prime} 53^{\prime \prime}$ & $24,723.1$ \\
6 & 17122000 & Rio dos Peixes & Rio dos Peixes & Juara & 6 & $2000-2007$ & $-10^{\circ} 82^{\prime} 00^{\prime \prime}$ & $-57^{\circ} 72^{\prime} 00^{\prime \prime}$ & $14,410.5$ \\
7 & 17091000 & Fazenda Tucunaré & Juruena & Sapezal & 9 & $1993-2013$ & $-13^{\circ} 27^{\prime} 39^{\prime \prime}$ & $-59^{\circ} 00^{\prime} 28^{\prime \prime}$ & $4,357.9$ \\
\hline
\end{tabular}

For $\mathrm{Q}_{\max }$ analysis, the historical series of $\mathrm{Q}_{\max }$ for each stream-gauging station listed in Table 1 was first established. To do that, $\mathrm{Q}_{\max }$ was selected for each hydrological year of the historical series. The hydrological year in the Juruena River Basin starts in October (beginning of the rainy season) and ends in September (end of the dry period).

The maximum streamflows associated with different return periods $(\mathrm{Tr})$ were determined by subjecting the historical series of $\mathrm{Q}_{\max } \mathrm{values}$ to statistical analysis, so the theoretical probability model with the best fit to the data series could be identified. For maximum extreme events, the following distribution models were tested: Log-Pearson type 3 (Equation 1), Gamma (Equation 2), Gumbel-Maximum - Extreme Value Type 1 (Equation 3), and Lognormal (Equation 4) (Naghettini, 2016; Tucci, 2009). The probability distribution parameters were obtained by maximum likelihood method.

$f(x)=\frac{1}{x|\beta| \Gamma(\alpha)}\left(\frac{\ln \ln (x)-\gamma}{\beta}\right)^{\alpha-1} \exp \left[-\frac{\ln (x)-\gamma}{\beta}\right]$

Where: $\mathrm{f}(\mathrm{x})$ is the probability density function; $\mathrm{x}$ is the maximum flow $\left(\mathrm{m}^{3} \mathrm{~s}^{-1}\right) ; \alpha, \beta$, and $\gamma$ are the distribution parameters.

$f(x)=\frac{(x-\gamma)^{\alpha-1}}{\beta^{\alpha} \Gamma(\alpha)} \exp \left(-\frac{(x-\gamma)}{\beta}\right)$

Where: $\mathrm{f}(\mathrm{x})$ is the probability density function; $\mathrm{x}$ is the maximum flow $\left(\mathrm{m}^{3} \mathrm{~s}^{-1}\right) ; \alpha, \beta$, and $\gamma$ are the distribution parameters.

$f(x)=\frac{1}{\sigma} \exp (-z-\exp (-z))$

Where: $\mathrm{f}(\mathrm{x})$ is the probability density function; $\mathrm{z}$ is equal to $(\mathrm{x}-\mu) / \sigma ; \mathrm{x}$ is the maximum flow $\left(\mathrm{m}^{3} \mathrm{~s}^{-1}\right) ; \mu$ and $\sigma$ are the distribution parameters.

$f(x)=\frac{\exp \left(-\frac{1}{2}\left(\frac{\ln \ln (x-\gamma)-\mu}{\sigma}\right)^{2}\right)}{(x-\gamma) \sigma \sqrt{2 \pi}}$

Where: $\mathrm{f}(\mathrm{x})$ is the probability density function; $\mathrm{x}$ is the maximum flow $\left(\mathrm{m}^{3} \mathrm{~s}^{-1}\right) ; \mu, \gamma$, and $\sigma$ are the distribution parameters. 
To check whether the probability distribution adhered to the maximum streamflow data, the Kolmogorov-Smirnov test was used at $20 \%$ significance level, as described by Naguettini (2016). Then, equations were developed based on the most common return periods in hydrological studies. In this case, the return period of a maximum event was considered inversely proportional to its occurrence probability, being equal or exceeded. After selecting the probability distribution that best fitted the data, the values of $\mathrm{Q}_{\max }$ associated with the return periods of 10,20, 50,100, 500, and 10,000 years were then estimated.

For minimum stream flows associated with $95 \%$ permanence $\left(\mathrm{Q}_{95}\right)$, a permanence curve had to be built. For this purpose, the historical series of daily streamflows recorded by the stream-gauging stations were used, using the procedure described by Pruski et al. (2006). Which consist of the analysis of streamflow frequency data; for that, 50 classes of daily streamflow data were defined, with interval subdivision $(\Delta X)$ obtained with Equation 5.

$\Delta \mathrm{X}=\frac{\left[\ln \left(\mathrm{Q}_{\max }\right)-\ln \left(\mathrm{Q}_{\min }\right)\right]}{50}$

Where: $\mathrm{Q}_{\max }$ is the biggest value of streamflow in the historical series $\left(\mathrm{m}^{3} \mathrm{~s}^{-1}\right)$; and $\mathrm{Q}_{\min }$ is the lowest value of streamflow registered in the historical series $\left(\mathrm{m}^{3} \mathrm{~s}^{-1}\right)$.

Then, were obtained the interval limits, from $\mathrm{Q}_{\min }$ adding the $(\Delta \mathrm{X})$ value previously calculated, establishing this way, the upper streamflow limit on every interval i (Equation 6).

$$
Q_{i+1}=\exp \left[\ln \ln \left(Q_{i}\right)+\Delta X\right]
$$

A frequency determination (fi) associated with the lower limit of each interval was subsequently performed, based on the historical series of the streamflow data of every gauging station and the number of classified streamflows in each interval (Equation 7). After the frequency calculus, the biggest class of streamflow to the lowest class was accumulated.

$$
f_{i}=\frac{N_{q i}}{N T} 100
$$

Where: $\mathrm{N}_{\mathrm{qi}}$ is the number of streamflows of each interval; and NT is the total number of streamflows.

The permanency curve was obtained by plotting every lower limit of streamflow of each interval in the ordinates axis and the accumulated occurrence frequency in the abscissa axis. The streamflow Q95 was extracted from the graph considering a 95\% of permanence in the abscissa axis and his value belongs to the ordinates axis.

Finally, long-term mean streamflow $\left(\mathrm{Q}_{\mathrm{ltm}}\right)$ was determined by means of the arithmetic mean of all daily streamflows in the historical series.

The traditional method proposed by Eletrobras (1985) was used for streamflow regionalization. This approach uses linear or nonlinear regression analysis to investigate how changes in independent variables may affect changes in the dependent variables. The streamflows $\mathrm{Q}_{95}, \mathrm{Q}_{\max }$, and $\mathrm{Q}_{1 \mathrm{tm}}$ were considered as dependent variables, while the physiographic features of the drainage areas upstream of every gauging station (Figure 1) were considered as independent variables.

The physiographic characteristics were determined by means of geographic information system (GIS), using the Shuttle Radar Topography Mission (SRTM) digital elevation model (MDE), with a spatial resolution of 90 meters, and the vector hydrography provided by the Brazilian Institute of Geography and Statistics (IBGE, 2015), at a scale of 1:250,000.

For sub-basins, physiographic parameters were obtained by the following five steps: (1) generation of a Hydrographically-Conditioned Digital Elevation Model (HCDEM) and removal of spurious depressions, (2) flow direction determination, (3) cumulative-flow direction 
determination, (4) numerical hydrography extraction, and (5) automatic sub-basin delineation. Detailed descriptions can be obtained in Lorenzon et al. (2015). ArcGIS software was used to perform the above procedures.

As independent variables, we used the following physiographic traits of the sub-basins: drainage area $\left(A_{D}, k^{2}\right)$, perimeter $(P, k m)$, total watercourse length $\left(L_{T}, k m\right)$, axial length $(L$, $\mathrm{km})$, basin mean elevation (Alt., meters), and basin mean slope (D, $\mathrm{m} / \mathrm{m})$. These characteristics were obtained following the procedures described by Villela and Mattos (1975) and by Wenzel et al. (2017).

The relationships among the above parameters were evaluated (Equation 8) using linear (Equation 9), potential (Equation 10), and exponential (Equation 11) regression models, and logarithm (Equation 12), as suggested in the adopted method.

$$
\begin{aligned}
& \widehat{\mathrm{Q}}=\mathrm{F}\left(\mathrm{A}_{\mathrm{D}}, \mathrm{P}, \mathrm{L}_{\mathrm{T}}, \mathrm{L}, \text { Alt. }, \mathrm{D}\right) \\
& \widehat{\mathrm{Q}}=\beta_{0}+\beta_{1} \mathrm{~A}_{\mathrm{D}}+\beta_{2} \mathrm{P}+\beta_{3} \mathrm{~L}_{\mathrm{T}}+\beta_{4} \mathrm{~L}+\beta_{5} \text { Alt. }+\beta_{6} \mathrm{D} \\
& \widehat{\mathrm{Q}}=\beta_{0} \mathrm{~A}_{\mathrm{D}}^{\beta 1} \mathrm{P}^{\beta 2} \mathrm{~L}_{\mathrm{T}}^{\beta 3} \mathrm{~L}^{\beta 4} \text { Alt. }^{\beta 5} \mathrm{D}^{\beta 6} \\
& \widehat{Q}=e^{\beta 0 A D^{\beta 1}} \mathrm{P}^{\beta 2} \mathrm{LT}^{\beta 3} \mathrm{~L}^{\beta 4} \mathrm{Alt} \cdot{ }^{\beta 5} \mathrm{D}^{\beta 6} \\
& \left.\mathrm{Q}=\beta_{0}+\beta_{1} \ln \left(\mathrm{A}_{\mathrm{D}}\right)+\beta_{2} \ln (\mathrm{P})+\beta_{3} \ln \widehat{\left(\mathrm{L}_{\mathrm{T}}\right.}\right)+\beta_{4} \ln (\mathrm{L})+\beta_{5} \ln (\text { Alt. })+\beta_{6} \ln (\mathrm{D})
\end{aligned}
$$

Where: $\hat{Q}$ is the estimated flow $\left(\mathrm{m}^{3} \mathrm{~s}^{-1}\right) ; \beta_{0}, \beta_{1}, \beta_{2}, \beta_{3}, \beta_{4}, \beta_{5}$, and $\beta_{6}$ are the coefficients of regression equations; and $\mathrm{A}_{\mathrm{D}}, \mathrm{P}, \mathrm{L}_{\mathrm{T}}, \mathrm{L}$, Alt., and $\mathrm{D}$ are the independent variables (i.e., physiographic characteristics upstream of each stream-gauging station). The statistical significance of each model (Equations 9 to 12) was assessed by the F-test for regression at $\alpha=$ $5 \%$.

The statistical measures used to check the performance of regression equations in estimating $\mathrm{Q}_{\max }, \mathrm{Q}_{95}$, and $\mathrm{Q}_{1 \mathrm{tm}}$ were: mean absolute error - MAE (Equation 13), root mean square error - RMSE (Equation 14), bias (Equation 15), paired t-test at 5\% significance (Equation 16), Willmott's agreement index (Equation 17), and Nash-Sutcliffe efficiency index (Equation 18) (Uliana et al., 2016), which were obtained respectively by the below Equations:

$$
\begin{aligned}
& \text { MAE }=\frac{1}{N} \sum_{i=1}^{\mathrm{N}}|\mathrm{Oi}-\mathrm{Pi}| \\
& \text { RMSE }=\left[\frac{1}{\mathrm{~N}} \sum_{\mathrm{i}=1}^{\mathrm{N}}(\mathrm{Oi}-\mathrm{Pi})^{2}\right] 0.5 \\
& \text { bias }=\frac{1}{\mathrm{~N}} \sum_{\mathrm{i}=1}^{\mathrm{N}}(\mathrm{Oi}-\mathrm{Pi}) \\
& \mathrm{t}=\sqrt{\left[\frac{(\mathrm{N}-1) \text { bias }^{2}}{\mathrm{RMSE}^{2}-\mathrm{bias}^{2}}\right]} \\
& \mathrm{d}=1-\left[\frac{\sum_{\mathrm{i}=1}^{\mathrm{N}}(\mathrm{Pi}-\mathrm{Oi})^{2}}{\sum_{\mathrm{i}=1}^{\mathrm{N}}(|\mathrm{Pi}-\mathrm{O}|+|\mathrm{Oi}-\mathrm{O}|)^{2}}\right] \\
& \mathrm{E}_{\mathrm{NS}}=1-\left[\frac{\sum_{\mathrm{i}=1}^{\mathrm{N}}(\mathrm{Oi}-\mathrm{Pi})^{2}}{\sum_{\mathrm{i}=1}^{\mathrm{N}}(\mathrm{Oi}-\mathrm{O})^{2}}\right]
\end{aligned}
$$

Where: $\mathrm{Pi}$ is the estimated streamflow, Oi is the observed streamflow, $\mathrm{O}$ is the mean of the observed streamflows, and $\mathrm{n}$ is the number of samples. 
Both MAE and RMSE measure the magnitude of error in a set of estimates (in units of a variable of interest). When equal to zero, they indicate a perfect model fit to the observed data series (Moriasi et al., 2007).

To diagnose error variations in the estimated streamflow series, MAE and RMSE were analyzed at the same time. RMSE will always be greater than or equal to MAE. The greater the difference between these errors, the greater the variance of individual errors in the sample. However, if they have equal values, it means all errors have the same order of magnitude.

Bias was used to verify underestimation (positive value) or overestimation (negative value) by the model.

The paired t-test at $5 \%$ significance was used to confirm if the difference $(\Delta)$ between the observed and simulated data was statistically null, which is an expected condition. The hypotheses of t-test were: $\mathrm{H}_{0}: \Delta=0$ and $\mathrm{H}_{1}: \Delta \neq 0$. When $\mathrm{t}$ value, in modulus, (Equation 16) was higher than the quantile of the Student's t-distribution, with $v=\mathrm{n}-1$ degrees of freedom $\left(\frac{\mathrm{t} \alpha}{2}, \mathrm{v}\right)$ then the null hypothesis $\left(\mathrm{H}_{0}\right)$ was rejected; that is, there is a difference between the observed and model-simulated streamflows, which is not desirable. The value of " $\mathrm{d}$ " varies between 0 and 1 , and values close to unity indicate agreement, i.e., the model has a better performance for predictions.

To evaluate the performance of models with respect to the Nash-Sutcliffe efficiency index (ENS), the classification suggested by Van Liew et al. (2007) was adopted. According to this classification: $E_{N S}=1$ means a perfect fit of the data predicted by the model, $E_{N S}>0.75$ indicates that the model is adequate and good, $0.36<\mathrm{E}_{\mathrm{NS}}<0.75$ indicates that the model is considered satisfactory, and $\mathrm{E}_{\mathrm{NS}}<0.36$ indicates that the model is inadequate.

To define the hydrological homogeneous regions, the same proposed procedure by Lisboa et al. (2008) was used. According to these authors, the regression determination coefficient, the significance model by the F-test at $5 \%$ of confidence, the classification of residual pattern and the error values between observed and estimated streamflows, must be analyzed. When satisfactory results were verified for those criteria, the region is defined as hydrologically homogeneous for the streamflows studied. Otherwise, it would be necessary to divide the region and regroup the gauging stations inside those regions and reanalyze a new adjustment for regionalization equations.

\section{RESULTS AND DISCUSSION}

\subsection{Minimum and Mean Streamflow}

Table 2 shows the regionalization equations of minimum streamflow with $95 \%$ permanence in the watercourse $\left(\mathrm{Q}_{95}\right)$ and long-term mean streamflow $\left(\mathrm{Q}_{1 \mathrm{tm}}\right)$ for the Juruena River Basin. Among the regression models tested (Equations 9 to 12), only linear and potential presented satisfactory adjustments to estimate the streamflows.

It can be seen in Table 2 that the physiographic features that allowed the best estimate of Q95 and $\mathrm{Q}_{1 \mathrm{tm}}$ were drainage area $\left(\mathrm{A}_{\mathrm{D}}\right)$, total watercourse length $\left(\mathrm{L}_{\mathrm{T}}\right)$ and basin mean elevation (Alt.).

Both $A_{D}$ and $L_{T}$ were obtained from SRTM digital elevation model with a spatial resolution of 90 meters, and $\mathrm{L}_{\mathrm{T}}$ from the vector hydrography data set of the IBGE at a scale of 1:250,000. Thus, the estimation of these independent variables was conditioned to the use of such databases.

In a preliminary analysis, we verified that both equations in Table 2 could properly estimate the dependent variables (i.e. flows) since the coefficient of determination was above 0.9. This result indicates that more than $90 \%$ of the total variances of the dependent variables ( $\mathrm{Q}_{95}$ and $\mathrm{Q}_{\mathrm{ltm}}$ ) were explained by the regression models that consider $\mathrm{A}_{\mathrm{D}}, \mathrm{L}_{\mathrm{T}}$, and Alt as independent variables. 
Table 2. Regionalization equations of minimum streamflow $\mathrm{Q}_{95}$ and long-term mean streamflow $\left(\mathrm{Q}_{\mathrm{ltm}}\right)$ for the Juruena River Basin.

\begin{tabular}{|c|c|c|c|c|c|c|c|}
\hline \multirow{2}{*}{ Flow } & \multirow{2}{*}{ Model } & \multirow{2}{*}{ ID } & \multirow{2}{*}{ Regionalization equation } & \multirow{2}{*}{$\mathbf{R}^{2}$} & \multicolumn{3}{|c|}{ IC $-95 \%$} \\
\hline & & & & & $\beta_{0}$ & $\beta_{1}$ & $\beta_{2}$ \\
\hline \multirow{4}{*}{$\mathrm{Q}_{95}$} & Linear & 1 & $\widehat{\mathrm{Q}}_{95}=29.200344+0.0118407\left(\mathrm{~A}_{\mathrm{D}}\right)$ & 0.93 & \pm 289.6 & $\pm 3.76 \mathrm{E}-03$ & - \\
\hline & \multirow{3}{*}{ Potential } & 2 & $\widehat{\mathrm{Q}}_{95}=0.0229462\left(\mathrm{~A}_{\mathrm{D}}\right)^{0.9459313}$ & 0.93 & \pm 0.101 & \pm 0.373 & - \\
\hline & & 3 & $\widehat{\mathrm{Q}}_{95}=0.0000441950\left(\mathrm{~A}_{\mathrm{D}}\right)^{3.52950055}\left(\mathrm{~L}_{\mathrm{T}}\right)^{-2.216318}$ & 0.99 & $\pm 5.5 \mathrm{E}-05$ & \pm 0.389 & \pm 4.119 \\
\hline & & 4 & $\widehat{Q}_{95}=3.651107 .10^{-10}\left(A_{D}\right)^{1.112025}(\text { Alt. })^{2.684034}$ & 0.99 & $\pm 1.11 \mathrm{E}-13$ & \pm 0.109 & \pm 0.666 \\
\hline \multirow{4}{*}{$Q_{\mathrm{ltm}}$} & \multirow{2}{*}{ Linear } & 5 & $\widehat{\mathrm{Q}}_{\mathrm{ltm}}=-73.964537+0.02564964\left(\mathrm{~A}_{\mathrm{D}}\right)$ & 0.99 & \pm 148.2 & $\pm 2.35 \mathrm{E}-03$ & - \\
\hline & & 6 & $\widehat{\mathrm{Q}}_{\mathrm{ltm}}=229.770514+0.030680\left(\mathrm{~A}_{\mathrm{D}}-1.474473(\mathrm{~L})\right.$ & 0.99 & \pm 263.9 & $\pm 4.32 \mathrm{E}-03$ & \pm 1.203 \\
\hline & \multirow{2}{*}{ Potential } & 7 & $\widehat{\mathrm{Q}}_{\mathrm{ltm}}=0.01116658\left(\mathrm{~A}_{\mathrm{D}}\right)^{1.067962}$ & 0.99 & $\pm 1.2 \mathrm{E}-02$ & \pm 0.091 & - \\
\hline & & 8 & $\widehat{\mathrm{Q}}_{\mathrm{ltm}}=0.00021135\left(\mathrm{~A}_{D}\right)^{1.099310}(\text { Alt. })^{0.604282}$ & 0.99 & $\pm 7.76 \mathrm{E}-04$ & \pm 0.069 & \pm 0.536 \\
\hline
\end{tabular}

$Q_{95}$ is the minimum flow with permanence of $95 \%\left(\mathrm{~m}^{3} \mathrm{~s}^{-1}\right)$; $\mathrm{Q}_{\mathrm{ltm}}$ is the long-term mean flow $\left(\mathrm{m}^{3} \mathrm{~s}^{-1}\right) ; A_{D}$ is the drainage area $\left(\mathrm{km}^{2}\right) ; \mathrm{L}_{\mathrm{T}}$ is the total watercourse length $(\mathrm{km})$, at a scale of 1:250,000; $\mathrm{L}$ is the axial length of the basin $(\mathrm{km})$; Alt. is the mean elevation of the basin $(\mathrm{m}) ; \mathrm{R}^{2}$ is the coefficient of determination; IC is the confidence interval $(95 \%)$ for the parameters of the regression equation; $\beta_{0}$, $\beta_{1}$ e $\beta_{2}$ are the parameters of the regressions equations according the Equations from 8 to 12.

In addition to a high $\mathrm{R}^{2}$, the F-test confirmed that there was a significant relationship between the dependent $\left(\mathrm{Q}_{95}\right.$ and $\left.\mathrm{Q}_{\mathrm{ltm}}\right)$ and independent $\left(\mathrm{A}_{\mathrm{D}}, \mathrm{L}_{\mathrm{T}}\right.$, and $\left.\mathrm{Alt}\right)$ variables.

A detailed error analysis of the regionalization equations (in Table 2) is required since only $\mathrm{R}^{2}$ and the F-test for regression are insufficient to consolidate the use of the equations. Thus, Table 3 shows a statistical error analysis of the regression models in Table 2.

After analyzing the Nash-Sutcliffe efficiency indexes ( $\left.E_{N S}\right)$ in Table 3, it can be stated according to Van Liew et al. (2007) that the regression models proposed for regionalization of $\mathrm{Q}_{95}$ and $\mathrm{Q}_{\mathrm{ltm}}$ are adequate and good, given that all $\mathrm{E}_{\mathrm{NS}}$ values were greater than 0.75.

The Willmott's agreement indexes (d) were near to 1, indicating a concordance between observed and predicted values.

As for the paired t-test, all values were not significant at 5\% significance. This confirms that the values of $\mathrm{Q}_{95}$ and $\mathrm{Q}_{1 \mathrm{tm}}$ observed by monitoring sections in the Juruena River Basin and those estimated by the regression equations in Table 2 have no significant difference, which is desirable.

As for MAE and RMSE, Table 3 shows that the distance between them is not large. This indicates that the variance of individual errors in the sample does not present an expressive value. It should be emphasized that if the values of MAE and RMSE were equal, all errors would have the same order of magnitude.

The bias values of equations in Table 2 indicated an overestimation (negative value) of $\mathrm{Q}_{95}$ and $\mathrm{Q}_{1 \mathrm{tm}}$ by the Equations ID 1, 2, and 6. Conversely, the other equations showed an underestimation (positive value) of $\mathrm{Q}_{95}$ and $\mathrm{Q}_{\mathrm{ltm}}$.

When analyzing all statistical indices in Table 3 together, the best equation for regionalization of $\mathrm{Q}_{95}$ flow was considering $\mathrm{A}_{\mathrm{D}}$ and $\mathrm{L}_{\mathrm{T}}$ as independent variables in the potential model (ID 3 - Table 2). This equation showed a value of MAE equal to $14.1 \mathrm{~m}^{3} \mathrm{~s}^{-1}$ and RMSE of $17.5 \mathrm{~m}^{3} \mathrm{~s}^{-1}$.

The second-best equation for regionalization of $\mathrm{Q}_{95}$ streamflow was the one that considered $A_{D}$ and Alt. as independent variables in the potential model (ID 4 - Table 2). In this equation, MAE and RMSE were equal to 20.4 and $31.1 \mathrm{~m}^{3} \mathrm{~s}^{-1}$, respectively. 
Table 3. Statistical error analysis of regression models in Table 2 for regionalization of $\mathrm{Q}_{95}$ and $\mathrm{Q}_{\mathrm{ltm}}$ streamflows.

\begin{tabular}{|c|c|c|c|c|c|c|c|c|c|}
\hline Flow & Model & ID & VI & MAE & RMSE & bias & d & $\mathbf{E}_{\mathrm{NS}}$ & $\mathbf{t}$ \\
\hline \multirow{4}{*}{$\mathrm{Q}_{95}$} & Linear & 1 & $A_{D}$ & 130.6 & 181.3 & $-2.08 \mathrm{E}-04$ & 0.981 & 0.930 & $2.81 \mathrm{E}-06^{(\mathrm{ns})}$ \\
\hline & \multirow{3}{*}{ Potential } & 2 & $A_{D}$ & 131.6 & 180.0 & -3.4 & 0.982 & 0.931 & $4.57 \mathrm{E}-02^{(\mathrm{ns})}$ \\
\hline & & 3 & $\mathrm{~A}_{\mathrm{D}} ; \mathrm{L}_{\mathrm{T}}$ & 14.1 & 17.5 & 5.3 & 0.999 & 0.999 & $7.73 \mathrm{E}-01^{(\mathrm{ns})}$ \\
\hline & & 4 & $A_{D} ;$ Alt. & 20.4 & 31.1 & 0.9 & 0.999 & 0.998 & $7.38 \mathrm{E}-02^{(\mathrm{ns})}$ \\
\hline \multirow{4}{*}{$\mathrm{Q}_{\mathrm{ltm}}$} & \multirow{2}{*}{ Linear } & 5 & $A_{D}$ & 84.1 & 92.8 & 3.0 & 0.999 & 0.996 & $7.92 \mathrm{E}-02^{(\mathrm{ns})}$ \\
\hline & & 6 & $A_{D} ; L$ & 36.1 & 47.0 & -0.01 & 0.999 & 0.999 & $2.95 \mathrm{E}-04^{(\mathrm{ns})}$ \\
\hline & \multirow{2}{*}{ Potential } & 7 & $A_{D}$ & 64.9 & 79.9 & 6.0 & 0.999 & 0.997 & $1.83 \mathrm{E}-01^{(\mathrm{ns})}$ \\
\hline & & 8 & $A_{D} ;$ Alt. & 32.8 & 44.0 & 6.9 & 0.999 & 0.999 & $3.91 \mathrm{E}-01^{(\mathrm{ns})}$ \\
\hline
\end{tabular}

$\mathrm{Q}_{95}$ is the minimum flow with permanence of $95 \%\left(\mathrm{~m}^{3} \mathrm{~s}^{-1}\right)$; $\mathrm{Q}_{\mathrm{ltm}}$ is the long-term mean flow $\left(\mathrm{m}^{3} \mathrm{~s}^{-1}\right)$; ID is the identification of the regionalization equation in Table 2; VI: independent variables; $A_{D}$ is the drainage area $\left(\mathrm{km}^{2}\right) ; \mathrm{L}_{\mathrm{T}}$ is the total watercourse length $(\mathrm{km})$, at a scale of 1:250,000; $\mathrm{L}$ is the axial length of the basin $(\mathrm{km})$; Alt. is the mean elevation of the basin $(\mathrm{m})$; MAE is the mean absolute error $\left(\mathrm{m}^{3} \mathrm{~s}^{-1}\right)$; RMSE is the root mean square error $\left(\mathrm{m}^{3} \mathrm{~s}^{-1}\right)$; Bias $\left(\mathrm{m}^{3} \mathrm{~s}^{-1}\right)$; $\mathrm{d}$ is the Willmott's agreement index; $E_{N S}$ is the Nash-Sutcliffe efficiency index; $t$ is the value of the paired t-test statistics; (ns): non-significant at 5\% significance; *: significant at $5 \%$.

Despite the best performance for estimating $Q_{95}$, the equation considering the variables $A_{D}$ and $\mathrm{L}_{\mathrm{T}}$ (ID 3 - Table 2) has a limitation. Such a restriction is due to a dependence of the total watercourse length on the used scale $(1: 250,000)$. When considering this scale, some watercourses in the basin, especially the smaller ones, may not be included, making this equation unsuitable for use. Thus, in such a situation, a suitable solution would be using Equation ID 4 (Table 2), which considers $A_{D}$ and Alt. variables as input data.

Although Equation ID 1 (Table 2) presents a greater error compared to the others, it still has an acceptable performance to estimate $\mathrm{Q}_{95}$ and a differential from the others. It considers $A_{D}$ as the independent variable and is of easy estimation in a GIS application. Considering only this variable, the equation is easily implemented and hence has a greater chance of becoming operational in technical studies to be performed in the hydrographic basin. The result of regionalization of $\mathrm{Q}_{95}$ with Equation ID 1 is shown in Figure 2. In this Figure, we considered only the stretches of watercourses with a drainage area larger than $4,000 \mathrm{~km}^{2}$.

As for $\mathrm{Q}_{\mathrm{ltm}}$, Table 3 highlights that the best estimation equation was the one using $\mathrm{A}_{\mathrm{D}}$ and Alt. as input variables in the potential model (ID 8 - Table 2). In this equation, MAE and RMSE were 32.8 and $44.0 \mathrm{~m}^{3} \mathrm{~s}^{-1}$, respectively.

The other equation with the best performance to estimate $\mathrm{Q}_{1 \mathrm{tm}}$ was considering $\mathrm{A}_{\mathrm{D}}$ and $\mathrm{L}$ as input variables in the linear model (ID 6 - Table 2).

The Equation ID 7 (Table 2) containing variable $A_{D}$ in the potential model presented good results for the determination of $\mathrm{Q}_{\mathrm{ltm}}$. In this case, the previous discussion is also valid. Regionalization equations that have only drainage area as a variable are easily implemented. Even though the error is greater compared to equations considering $\mathrm{L}$ and Alt., they are still reliable for estimating $\mathrm{Q}_{\mathrm{ltm}}$. The result of regionalization of $\mathrm{Q}_{\mathrm{ltm}}$ using Equation ID 7 (Table 2) can be seen in Figure 2 (b).

Once the accuracy and precision of $\mathrm{Q}_{95}$ and $\mathrm{Q}_{1 \mathrm{tm}}$ regionalization equations were confirmed, the region of the Juruena River Basin can be considered hydrologically homogeneous. 
Talisson Sáteles Matos et al.
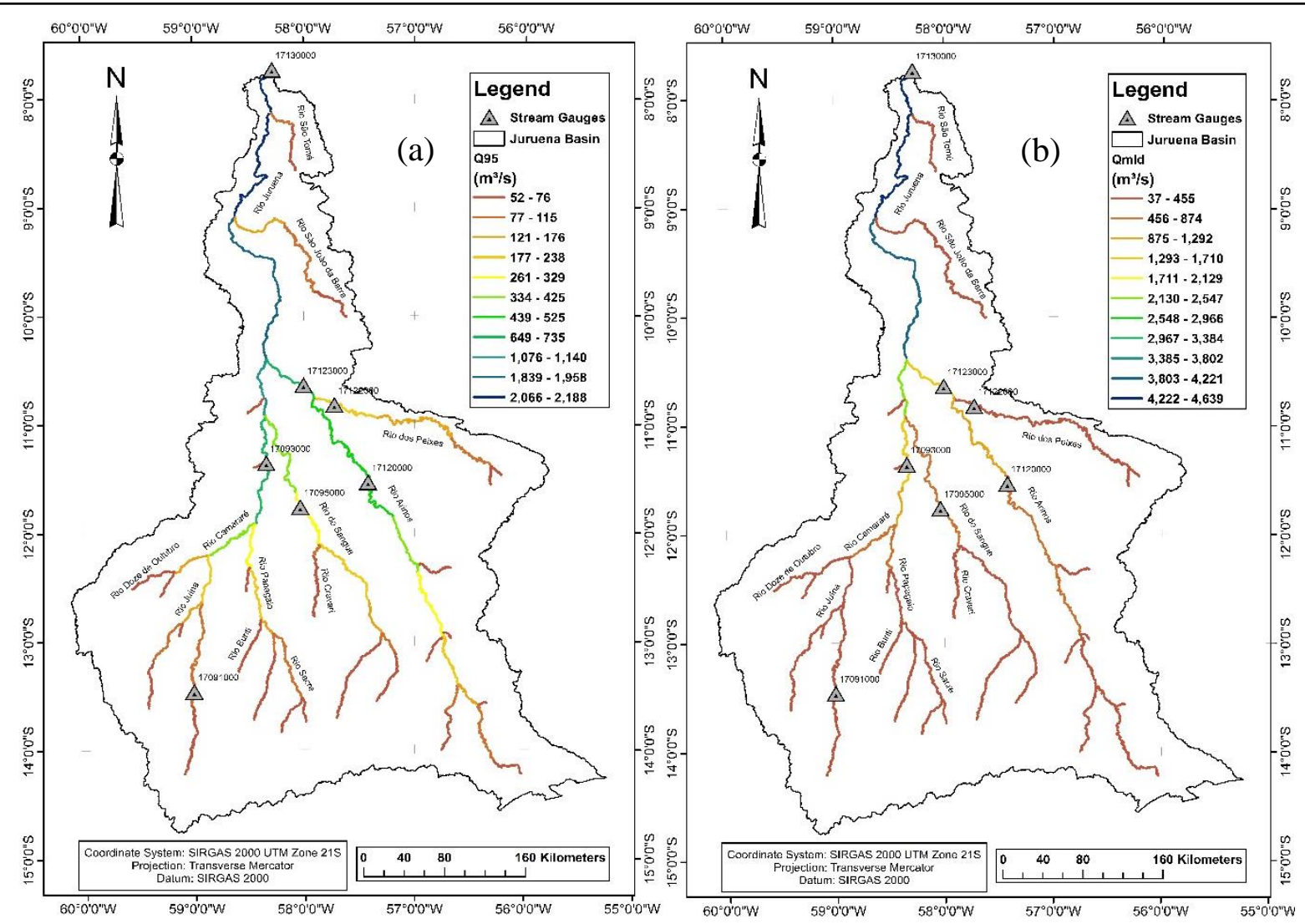

Figure 2. Estimation of $\mathrm{Q}_{95}$ (a) and $\mathrm{Q}_{\mathrm{ttm}}$ (b) using the regionalization Equations ID 1 and ID 7 in Table 2, respectively.

\subsection{Maximum Streamflow (Qmax.)}

Among the theoretical probability models tested for the estimation of $\mathrm{Q}_{\max }$ for different return periods (Tr), the Log-Pearson type 3 distribution (Equation 1) was the one that presented the best fit to the data series. This outcome can be confirmed by the p-value of the KolmogorovSmirnov test in Table 4.

Table 4 also lists the parameters of the Log-Pearson type 3 distribution, which allows the estimation of $\mathrm{Q}_{\max }$ for periods of return different from those addressed in this study. Table 5 presents the values of $Q_{\max }\left(\mathrm{m}^{3} \mathrm{~s}^{-1}\right)$ associated with the return periods of the Juruena River Basin.

The Table 6 shows the confidence interval (95\%) for maximum streamflows on the basin of the Juruena River associated with different return periods. It shows that for higher return periods, mostly for 500 and 10,000 years, the associated uncertainty in estimation is bigger. That uncertainty is bigger even on gauging stations with smaller historical series like foz do Juruena (17130000), Rio Arinos (17123000) and Rio dos Peixes (17122000). That uncertainty should be considered on hydraulic-structure projects which would be done within basins.

In Table 7, we can observe the regionalization equations of $\mathrm{Q}_{\max }$ associated with the return periods $(\mathrm{T})$ of $10,20,50,100,500$, and 10,000 years

Among the regression models tested, only linear and potential models presented adequate results for regionalization of $\mathrm{Q}_{\max }$. In this case, the independent variables that provided the best results were $A_{D}, L_{T}$, and $P$.

All regressions in Table 7 presented significant F-test results. Also, in this table, the equations showed $\mathrm{R}^{2}$ values of 0.98 or 0.99 , which are desirable. Thus, more than $98 \%$ of the variance of $Q_{\max }$ was explained by the variables $A_{D}, P$, and $L_{T}$.

The linear regression model showed good results when only the independent variable LT was used. 
Table 4. P-value of the Kolmogorov-Smirnov test and the parameters of Log-Pearson type 3 theoretical probability distribution.

\begin{tabular}{ccccccc}
\hline Code & ID & Station & P-value & $\boldsymbol{\alpha}$ & $\beta$ & $\gamma$ \\
\hline 17130000 & 1 & Foz Juruena & 0.978 & 68.243 & $-1.386 \mathrm{E}-02$ & 10.121 \\
17093000 & 2 & Fontanilhas & 0.956 & $33,382.0$ & $4.047 \mathrm{E}-04$ & -5.8633 \\
17123000 & 3 & Rio Arinos & 0.994 & 100.790 & $1.375 \mathrm{E}-02$ & 6.5178 \\
17120000 & 4 & Porto dos Gaúchos & 0.996 & 12.143 & $4.389 \mathrm{E}-02$ & 6.6887 \\
17095000 & 5 & Faz. Tombador & 0.999 & 71.323 & $1.211 \mathrm{E}-02$ & 5.9182 \\
17122000 & 6 & Rio dos Peixes & 0.898 & 6.487 & $-7.654 \mathrm{E}-02$ & 7.2827 \\
17091000 & 7 & Faz. Tucunaré & 0.887 & 582.732 & $3.444 \mathrm{E}-03$ & 3.2119 \\
\hline
\end{tabular}

ID: identification number of the station on the map (Figure 1); P-value of the Kolmogorov-Smirnov test; $\alpha, \beta$, and $\gamma$ are the adjusted parameters of the Log-Pearson type 3 distribution.

Table 5. Maximum streamflows $\left(\mathrm{m}^{3} \mathrm{~s}^{-1}\right)$ associated with different return periods $(\mathrm{T})$ and estimated using the Log-Pearson type 3 probability distribution.

\begin{tabular}{ccccccccc}
\hline \multirow{2}{*}{ Code } & \multirow{2}{*}{ ID } & \multirow{2}{*}{ Station } & \multicolumn{6}{c}{ Return Period (T) - Years } \\
\cline { 4 - 9 } & & & $\mathbf{1 0}$ & $\mathbf{2 0}$ & $\mathbf{5 0}$ & $\mathbf{1 0 0}$ & $\mathbf{5 0 0}$ & $\mathbf{1 0 , 0 0 0}$ \\
\hline 17130000 & 1 & Foz Juruena & $11,133.0$ & $11,549.0$ & $12,019.0$ & $12,333.0$ & $12,969.0$ & $13,933.0$ \\
17093000 & 2 & Fontanilhas & $2,302.8$ & $2,365.8$ & $2,439.0$ & $2,489.1$ & $2,593.8$ & $2,762.2$ \\
17123000 & 3 & Rio Arinos & $3,239.5$ & $3,422.7$ & $3,646.8$ & $3,807.6$ & $4,164.5$ & $4,801.1$ \\
17120000 & 4 & Porto dos Gaúchos & $1,676.8$ & $1,800.2$ & $1,959.8$ & $2,080.4$ & $2,365.7$ & $2,935.5$ \\
17095000 & 5 & Faz. Tombador & $1,007.6$ & $1,050.3$ & $1,101.9$ & $1,138.6$ & $1,219.1$ & $1,359.7$ \\
17122000 & 6 & Rio dos Peixes & $1,112.0$ & $1,162.0$ & $1,213.1$ & $1,244.0$ & $1,298.6$ & $1,362.0$ \\
17091000 & 7 & Faz. Tucunaré & 204.8 & 212.2 & 219.9 & 225.3 & 236.6 & 255.4 \\
\hline
\end{tabular}

ID: identification number of the station on the map (Figure 1).

Table 6. Confidence intervals $95 \%\left(\mathrm{~m}^{3} \mathrm{~s}^{-1}\right)$ for the maximum stream flows associated with different return periods shown in Table 5 .

\begin{tabular}{ccccccccc}
\hline \multirow{2}{*}{ Code } & ID & Station & \multicolumn{6}{c}{ Confidence Intervals - 95\% } \\
\cline { 4 - 9 } & & $\mathbf{1 0}$ & $\mathbf{2 0}$ & $\mathbf{5 0}$ & $\mathbf{1 0 0}$ & $\mathbf{5 0 0}$ & $\mathbf{1 0 , 0 0 0}$ \\
\hline 17130000 & 1 & Foz Juruena & $\pm 1,473.3$ & $\pm 1,786.2$ & $\pm 2,195.4$ & $\pm 4,158.5$ & $\pm 3,199.1$ & $\pm 4,473.9$ \\
17093000 & 2 & Fontanilhas & \pm 82.1 & \pm 96.1 & \pm 114.0 & \pm 127.3 & \pm 156.7 & \pm 207.9 \\
17123000 & 3 & Rio Arinos & \pm 377.8 & \pm 454.4 & \pm 557.0 & \pm 636.0 & \pm 821.0 & $\pm 1,178.3$ \\
17120000 & 4 & Porto dos Gaúchos & \pm 162.2 & \pm 205.5 & \pm 266.6 & \pm 315.8 & \pm 441.2 & \pm 722.3 \\
17095000 & 5 & Faz. Tombador & \pm 60.5 & \pm 72.3 & \pm 87.5 & \pm 99.1 & \pm 125.9 & \pm 176.3 \\
17122000 & 6 & Rio dos Peixes & \pm 230.8 & \pm 282.7 & \pm 349.3 & \pm 398.9 & \pm 508.8 & \pm 699.4 \\
17091000 & 7 & Faz. Tucunaré & \pm 14.5 & \pm 17.2 & \pm 20.6 & \pm 23.0 & \pm 28.7 & \pm 38.7 \\
\hline
\end{tabular}


Table 7. Regionalization equations of maximum streamflow $\left(\mathrm{Q}_{\max }\right)$ associated with different return periods $(\mathrm{T})$ of the Juruena River Basin.

\begin{tabular}{|c|c|c|c|c|c|c|}
\hline \multirow{2}{*}{$\mathbf{T}($ years $)$} & \multirow{2}{*}{ Model } & \multirow{2}{*}{ ID } & \multirow{2}{*}{ Equation } & \multirow{2}{*}{$\mathbf{R}^{2}$} & \multicolumn{2}{|c|}{ IC $-95 \%$} \\
\hline & & & & & $\beta_{0}$ & $\beta_{1}$ \\
\hline \multirow{4}{*}{10} & Linear & 1 & $\widehat{\mathrm{Q}}_{\max }=-14.002950+0.136674\left(\mathrm{~L}_{\mathrm{T}}\right)$ & 0.99 & \pm 209.88 & $\pm 6.33 \mathrm{E}-03$ \\
\hline & & 2 & $\widehat{\mathrm{Q}}_{\max }=0.008445\left(\mathrm{~A}_{\mathrm{D}}\right)^{1.163076}$ & 0.99 & $\pm 1.66 \mathrm{E}-02$ & \pm 0.168 \\
\hline & Potential & 3 & $\widehat{\mathrm{Q}}_{\max }=0.000506(\mathrm{P})^{1.987922}$ & 0.99 & $\pm 1.31 \mathrm{E}-03$ & \pm 0.308 \\
\hline & & 4 & $\widehat{\mathrm{Q}}_{\max }=0.110875\left(\mathrm{~L}_{\mathrm{T}}\right)^{1.018699}$ & 0.99 & $\pm 7.51 \mathrm{E}-02$ & $\pm 6.13 \mathrm{E}-02$ \\
\hline \multirow{4}{*}{20} & Linear & 5 & $\widehat{\mathrm{Q}}_{\max }=3.429125+0.141698\left(\mathrm{~L}_{\mathrm{T}}\right)$ & 0.99 & \pm 191.53 & $\pm 5.3 \mathrm{E}-03$ \\
\hline & & 6 & $\widehat{\mathrm{Q}}_{\max }=0.009724\left(\mathrm{~A}_{\mathrm{D}}\right)^{1,154455}$ & 0.99 & $\pm 2.03 \mathrm{E}-02$ & \pm 0.174 \\
\hline & Potential & 7 & $\widehat{\mathrm{Q}}_{\max }=0.000605(\mathrm{P})^{1.971241}$ & 0.99 & $\pm 1.44 \mathrm{E}-03$ & \pm 0.283 \\
\hline & & 8 & $\widehat{Q}_{\max }=0.1252730\left(\mathrm{~L}_{\mathrm{T}}\right)^{1.0111630}$ & 0.99 & $\pm 7.57 \mathrm{E}-02$ & $\pm 5.48 \mathrm{E}-02$ \\
\hline \multirow{4}{*}{50} & Linear & 9 & $\widehat{\mathrm{Q}}_{\max }=28.686446+0.147359\left(\mathrm{~L}_{\mathrm{T}}\right)$ & 0.99 & \pm 171.42 & $\pm 5.14 \mathrm{E}-03$ \\
\hline & & 10 & $\widehat{\mathrm{Q}}_{\max }=0.011680\left(\mathrm{~A}_{\mathrm{D}}\right)^{1.142605}$ & 0.98 & $\pm 2.53 \mathrm{E}-02$ & \pm 0.181 \\
\hline & Potential & 11 & $\widehat{\mathrm{Q}}_{\max }=0.000762(\mathrm{P})^{1.948856}$ & 0.99 & $\pm 1.61 \mathrm{E}-03$ & \pm 0.251 \\
\hline & & 12 & $\widehat{\mathrm{Q}}_{\max }=0.146346\left(\mathrm{~L}_{\mathrm{T}}\right)^{1.000965}$ & 0.99 & $\pm 7.77 \mathrm{E}-02$ & $\pm 4.8 \mathrm{E}-02$ \\
\hline \multirow{4}{*}{100} & Linear & 13 & $\widehat{\mathrm{Q}}_{\max }=49.537503+0.151126\left(\mathrm{~L}_{\mathrm{T}}\right)$ & 0.99 & \pm 164.33 & $\pm 4.87 \mathrm{E}-03$ \\
\hline & & 14 & $\widehat{\mathrm{Q}}_{\max }=0.013399\left(\mathrm{~A}_{\mathrm{D}}\right)^{1.133403}$ & 0.98 & $\pm 2.96 \mathrm{E}-02$ & \pm 0.187 \\
\hline & Potential & 15 & $\widehat{\mathrm{Q}}_{\max }=0.000904(\mathrm{P})^{1.931770}$ & 0.99 & $\pm 1.74 \mathrm{E}-03$ & \pm 0.228 \\
\hline & & 16 & $\widehat{\mathrm{Q}}_{\max }=0.164127\left(\mathrm{~L}_{\mathrm{T}}\right)^{0.993126}$ & 0.99 & $\pm 8.29 \mathrm{E}-02$ & $\pm 4.6 \mathrm{E}-02$ \\
\hline \multirow{4}{*}{500} & Linear & 17 & $\widehat{\mathrm{Q}}_{\max }=103.381232+0.158707\left(\mathrm{~L}_{\mathrm{T}}\right)$ & 0.99 & \pm 193.20 & $\pm 6.3 \mathrm{E}-02$ \\
\hline & & 18 & $\widehat{Q}_{\max }=0.018379\left(A_{D}\right)^{1.111462}$ & 0.98 & $\pm 4.36 \mathrm{E}-02$ & \pm 0.199 \\
\hline & Potential & 19 & $\widehat{\mathrm{Q}}_{\max }=0.001336(\mathrm{P})^{1.89179259}$ & 0.99 & $\pm 1.97 \mathrm{E}-03$ & \pm 0.175 \\
\hline & & 20 & $\widehat{\mathrm{Q}}_{\max }=0.212920\left(\mathrm{~L}_{\mathrm{T}}\right)^{0.974605}$ & 0.99 & \pm 0.113 & $\pm 4.7 \mathrm{E}-02$ \\
\hline \multirow{4}{*}{10,000} & Linear & 21 & $\widehat{\mathrm{Q}}_{\max }=223.809866+0.170014\left(\mathrm{~L}_{\mathrm{T}}\right)$ & 0.99 & \pm 385.76 & $\pm 1.2 \mathrm{E}-02$ \\
\hline & & 22 & $\widehat{\mathrm{Q}}_{\max }=0.033007\left(\mathrm{~A}_{\mathrm{D}}\right)^{1.069047}$ & 0.98 & $\pm 8.8 \mathrm{E}-02$ & \pm 0.222 \\
\hline & Potential & 23 & $\widehat{\mathrm{Q}}_{\max }=0.002724(\mathrm{P})^{1.816706}$ & 0.99 & $\pm 1.99 \mathrm{E}-03$ & $\pm 8.6 \mathrm{E}-02$ \\
\hline & & 24 & $\widehat{\mathrm{Q}}_{\max }=0.341834\left(\mathrm{~L}_{\mathrm{T}}\right)^{0.939189}$ & 0.99 & \pm 0.282 & $\pm 7.5 \mathrm{E}-02$ \\
\hline
\end{tabular}

$A_{D}$ is the drainage area $\left(\mathrm{km}^{2}\right) ; \mathrm{P}$ is the perimeter of the basin $(\mathrm{km}) ; \mathrm{L}_{T}$ is the total watercourse length $(\mathrm{km}) ; \mathrm{R}^{2}$ is the coefficient of determination; IC is the confidence interval $(95 \%)$ for the parameters of the regression equation; $\beta_{0}, \beta_{1}$ e $\beta_{2}$ are the parameters of the regressions equations according the Equations from 8 to 12 .

Table 8 presents a statistical error analysis of the regionalization equations described in Table 7.

All equations used for regionalization of $\mathrm{Q}_{\max }$ presented Nash-Sutcliffe efficiency indexes (ENS) above 0.75, which indicates, according to Van Liew et al. (2007), that the models are adequate and good to estimate $\mathrm{Q}_{\max }$ associated with the analyzed return periods.

The values of Willmott's agreement index were near 1, indicating the good performance of equations in predicting $\mathrm{Q}_{\max }$ values.

The t-test indicated that the $\mathrm{Q}_{\max }$ values observed and predicted by equations in Table 7 did not show a significant difference at $5 \%$ significance. 
The slight difference between MAE and RMSE indicated that the variance of individual errors is small in both estimates, that is, most of the errors in equations are relatively minor.

Lastly, bias indicated an underestimate (positive value) of $\mathrm{Q}_{\max }$ rates by most of the proposed equations.

Table 8. Statistical error analysis of the regression models in Table 7 for the regionalization of maximum streamflow $\left(\mathrm{Q}_{\max }\right)$ associated with different return periods.

\begin{tabular}{|c|c|c|c|c|c|c|c|c|}
\hline $\mathbf{T}$ & ID & VI & MAE & RMSE & bias & d & $\mathbf{E}_{N S}$ & $\mathbf{t}$ \\
\hline \multirow{4}{*}{10} & 1 & $\mathrm{~L}_{\mathrm{T}}$ & 112.5 & 138.5 & $-1.4 \mathrm{E}-02$ & 0.9996 & 0.998 & $2.5 \mathrm{E}-04^{(\mathrm{ns})}$ \\
\hline & 2 & $A_{D}$ & 232.2 & 312.6 & 47.0 & 0.9980 & 0.992 & $3.7 \mathrm{E}-01^{(\mathrm{ns})}$ \\
\hline & 3 & $\mathrm{P}$ & 273.4 & 329.2 & 57.7 & 0.9978 & 0.991 & $4.4 \mathrm{E}-01^{(\mathrm{ns})}$ \\
\hline & 4 & $\mathrm{~L}_{\mathrm{T}}$ & 98.7 & 130.9 & 22.5 & 0.9996 & 0.999 & $4.3 \mathrm{E}-01^{(\mathrm{ns})}$ \\
\hline \multirow{4}{*}{20} & 5 & $\mathrm{~L}_{\mathrm{T}}$ & 97.0 & 126.4 & 0.0 & 0.9997 & 0.999 & $2.8 \mathrm{E}-04^{(\mathrm{ns})}$ \\
\hline & 6 & $A_{D}$ & 248.7 & 340.7 & 47.6 & 0.9978 & 0.991 & $3.5 \mathrm{E}-01^{\text {(ns) }}$ \\
\hline & 7 & $\mathrm{P}$ & 263.6 & 317.9 & 55.8 & 0.9981 & 0.992 & $4.4 \mathrm{E}-01^{(\mathrm{ns})}$ \\
\hline & 8 & $\mathrm{~L}_{\mathrm{T}}$ & 89.7 & 123.1 & 21.0 & 0.9997 & 0.999 & $4.3 \mathrm{E}-01^{(\mathrm{ns})}$ \\
\hline \multirow{4}{*}{50} & 9 & $\mathrm{~L}_{\mathrm{T}}$ & 93.4 & 113.1 & $2.9 \mathrm{E}-02$ & 0.9998 & 0.999 & $6.2 \mathrm{E}-04^{(\mathrm{ns})}$ \\
\hline & 10 & $A_{D}$ & 272.0 & 375.3 & 47.4 & 0.9975 & 0.990 & $3.1 \mathrm{E}-01^{(\mathrm{ns})}$ \\
\hline & 11 & $\mathrm{P}$ & 246.3 & 298.8 & 51.4 & 0.9984 & 0.994 & $4.3 \mathrm{E}-01^{(\mathrm{ns})}$ \\
\hline & 12 & $\mathrm{~L}_{\mathrm{T}}$ & 90.8 & 115.2 & 18.3 & 0.9998 & 0.999 & $3.9 \mathrm{E}-01^{(\mathrm{ns})}$ \\
\hline \multirow{4}{*}{100} & 13 & $\mathrm{~L}_{\mathrm{T}}$ & 93.9 & 108.5 & 0.0 & 0.9998 & 0.9992 & $3.2 \mathrm{E}-04^{(\mathrm{ns})}$ \\
\hline & 14 & $A_{D}$ & 294.9 & 400.8 & 46.2 & 0.9973 & 0.9890 & $2.8 \mathrm{E}-01^{(\mathrm{ns})}$ \\
\hline & 15 & $\mathrm{P}$ & 231.5 & 281.9 & 49.2 & 0.9987 & 0.9946 & $4.3 \mathrm{E}-01^{(\mathrm{ns})}$ \\
\hline & 16 & $\mathrm{~L}_{\mathrm{T}}$ & 96.3 & 113.1 & 15.7 & 0.9998 & 0.9991 & $3.4 \mathrm{E}-01^{\text {(ns) }}$ \\
\hline \multirow{4}{*}{500} & 17 & $\mathrm{~L}_{\mathrm{T}}$ & 100.4 & 127.5 & $-2.8 \mathrm{E}-14$ & 0.9997 & 0.9990 & $5.5 \mathrm{E}-16^{(\mathrm{ns})}$ \\
\hline & 18 & $A_{D}$ & 346.9 & 461.1 & 42.3 & 0.9967 & 0.9868 & $2.3 \mathrm{E}-01^{(\mathrm{ns})}$ \\
\hline & 19 & $\mathrm{P}$ & 189.5 & 235.5 & 40.5 & 0.9991 & 0.9966 & $4.3 \mathrm{E}-01^{(\mathrm{ns})}$ \\
\hline & 20 & $\mathrm{~L}_{\mathrm{T}}$ & 107.5 & 128.4 & 8.9 & 0.9997 & 0.9990 & $1.7 \mathrm{E}-01^{(\mathrm{ns})}$ \\
\hline \multirow{4}{*}{10,000} & 21 & $\mathrm{~L}_{\mathrm{T}}$ & 214.1 & 254.6 & $1.4 \mathrm{E}-02$ & 0.9991 & 0.9965 & $1.4 \mathrm{E}-04^{(\mathrm{ns})}$ \\
\hline & 22 & $A_{D}$ & 444.4 & 586.9 & 31.1 & 0.9953 & 0.9814 & $1.3 \mathrm{E}-01^{(\mathrm{ns})}$ \\
\hline & 23 & $\mathrm{P}$ & 109.0 & 133.0 & 15.9 & 0.9998 & 0.9990 & $2.9 \mathrm{E}-01^{(\mathrm{ns})}$ \\
\hline & 24 & $\mathrm{~L}_{\mathrm{T}}$ & 181.6 & 226.9 & -6.3 & 0.9993 & 0.9972 & $6.8 \mathrm{E}-02^{(\mathrm{ns})}$ \\
\hline
\end{tabular}

ID is the identification of the regionalization equation in Table 7; VI: independent variable; $A_{D}$ is the drainage area $\left(\mathrm{km}^{2}\right) ; \mathrm{P}$ is the perimeter of the basin $(\mathrm{km}) ; \mathrm{L}_{\mathrm{T}}$ is the total watercourse length $(\mathrm{km})$, at a scale of 1:250,000; MAE is the mean absolute error $\left(\mathrm{m}^{3} \mathrm{~s}^{-1}\right)$; RMSE is the root mean square error $\left(\mathrm{m}^{3} \mathrm{~s}^{-1}\right)$; Bias $\left(\mathrm{m}^{3} \mathrm{~s}^{-1}\right)$; $\mathrm{d}$ is the Willmott's agreement index; $\mathrm{E}_{\mathrm{NS}}$ is the Nash-Sutcliffe efficiency index; $t$ is the value of the paired $t$-test statistics; (ns): non-significant at 5\% significance.

For return periods from 10 to 500 years, the best performance to predict $\mathrm{Q}_{\max }$ was observed for linear and potential equations, using $\mathrm{L}_{\mathrm{T}}$ as an independent variable. For a return period of 10,000 years, the best performance was found for potential equations, using perimeter as a variable. 
We have previously discussed the limitation of using $\mathrm{L}_{\mathrm{T}}$ as an independent variable, provided the dimension of the scale $(1: 250,000)$. Therefore, in cases where the use of $\mathrm{L}_{\mathrm{T}}$ precludes prediction of streamflows, the potential equation using $A_{D}$ as independent variable could be used instead. This is confirmed by the statistical indices in Table 8 , which show that potential equations also have precision and accuracy, despite the higher values of MAE and RMSE. Figure 3 displays the application of potential equations to estimate $Q_{\max }$ in the study area.

As confirmed by the accuracy and precision of regionalization equations of $\mathrm{Q}_{\max }$, the region of the Juruena River Basin can be regarded as hydrologically homogeneous.
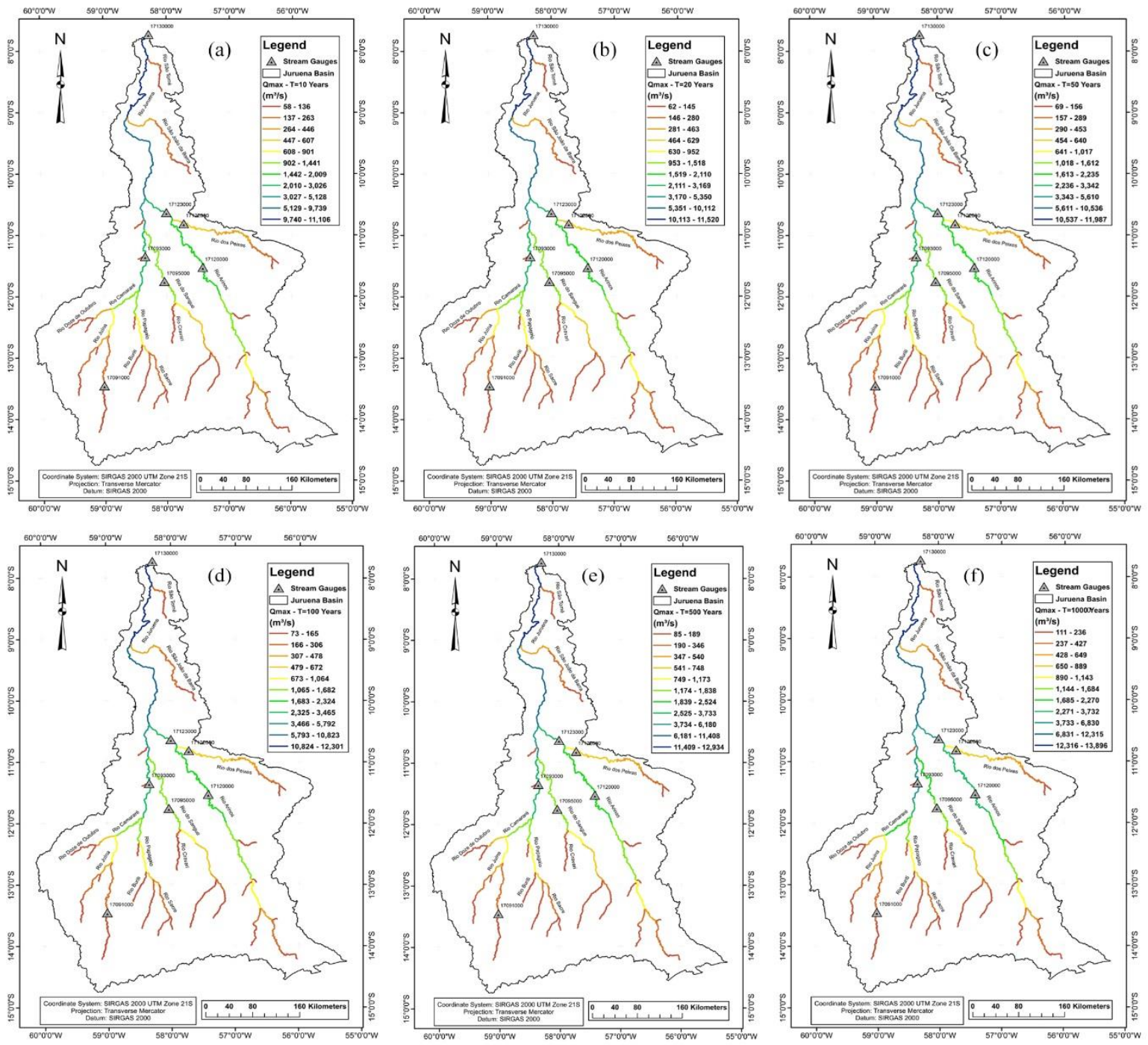

Figure 3. Estimation of maximum streamflow $\left(\mathrm{Q}_{\max }\right)$ for the return periods $(\mathrm{T})$ of $10(\mathrm{a}), 20$ (b), 50 (c), 100 (d), 500 (e), and 10,000 (f) years, using the regionalization Equations ID 2, 6, 10, 14, 18, and 22 in Table 7, respectively.

\section{FINAL CONSIDERATIONS}

The traditional method proved to be efficient for regionalization of $\mathrm{Q}_{95}, \mathrm{Q}_{1 \mathrm{tm}}$, and $\mathrm{Q}_{\max }$ in the Juruena River Basin. Our findings are similar to those reported by Pruski et al. (2013), Lopes et al. (2016; 2017), and Cecílio et al. (2018), who also used the traditional method for regionalization of maximum, minimum, and mean streamflows in basins located in other regions of Brazil. 
Some of the above-cited studies (e.g. Pruski et al., 2013) used rainfall as an explanatory variable in regionalization equations. We could not use it because of the low density of rain gauges in the Juruena River Basin and the convective nature of local rainfall. These peculiarities resulted in major errors in the cross-validation study of the rainfall spatialization by either ordinary kriging or inverse distance weighting. Due to this, rainfall was disregarded as a variable in regionalization equations.

The results obtained are promising, opening the way for further investigation, and may support hydrologists in the planning and management of surface water resources in the Juruena River Basin.

The Brazilian Irrigation Atlas (ANA, 2017) and surveys on central-pivot irrigation agriculture have pointed out an extensive irrigated area within the Juruena River Basin, which tends to increase in the coming years. Thus, this region needs proper planning to avoid conflicts over the use of water. In addition to the irrigated area, the basin has great potential for hydropower production, according to research developed by the EPE (2010).

The regionalization of minimum flow (Q95) will allow the development of water availability studies in the basin, wherein balances between supply and demand can be made. Thus, the areas under potential conflict and suitable for irrigation can be identified since the basin features agriculture and husbandry as its main economic activities.

The equations obtained in our study for regionalization of long-term mean streamflow $\left(\mathrm{Q}_{\mathrm{ltm}}\right)$ can be used in water reservoir projects to estimate the volume of water to be settled. Finally, the equations used for regionalization of maximum streamflow $\left(\mathrm{Q}_{\max }\right)$ will allow the designing of hydraulic structures in the watercourses of the basin.

Despite the good results, the regionalization equations obtained in this study can only be used in basins with drainage areas between $4,357.9$ and $182,458.3 \mathrm{~km}^{2}$. The hydrological behavior of small river basins was not considered due to the lack of gauging stations in such drainage areas. Therefore, the regionalization equations presented here can be cautiously extrapolated to small-scale drainage areas.

\section{CONCLUSIONS}

Maximum $\left(\mathrm{Q}_{\max }\right)$, minimum $\left(\mathrm{Q}_{95}\right)$, and long-term mean $\left(\mathrm{Q}_{\mathrm{ltm}}\right)$ streamflows were regionalized. Under the studied conditions, the following conclusions could be drawn:

- Only one hydrologically homogeneous region was identified for $\mathrm{Q}_{95}, \mathrm{Q}_{1 \mathrm{tm}}$, and $\mathrm{Q}_{\max }$ associated with different return periods;

- The traditional method was efficient for regionalization of $\mathrm{Q}_{95}, \mathrm{Q}_{\mathrm{ltm}}$, and $\mathrm{Q}_{\max }$ streamflows in the Juruena River Basin;

- Drainage area, total watercourse length, and sub-basin mean elevation were the explanatory variables that provided the best results for regionalization of $\mathrm{Q}_{95}$ and $\mathrm{Q}_{\mathrm{ltm}}$ in the Juruena River Basin. As for $\mathrm{Q}_{\max }$, the explanatory variables were drainage area, basin perimeter, and total watercourse length.

- The regionalization equations of $\mathrm{Q}_{\max }$ that considered total watercourse length as explanatory variables showed a smaller estimation error.

- The regionalization equations determined in this study were reliable and provide subsidies for the planning and management of water resources in the Juruena River Basin, mainly for flow regulation, water-use granting, and hydraulic design.

\section{ACKNOWLEDGMENTS}

The authors thank the Brazilian Coordination for Improvement of the Higher Education Personnel (CAPES) for the Master's degree scholarship provided. 


\section{REFERENCES}

ANA (Brasil). Atlas Irrigação: uso da água na agricultura irrigada. Brasília, 2017. 86p.

ALVES, E. C. R. F.; SILVINO, A. N. O.; ANDRADE, N. L. R.; SILVEIRA, A. Gestão dos Recursos Hídricos no Estado de Mato Grosso. Revista Brasileira de Recursos Hídricos, v. 14, n. 3, p. 69-80, 2009.

ARAI, F. K.; PEREIRA, S. B.; GONÇALVES, G. G. G. Characterization of water availability in a hydrographic basin. Engenharia Agrícola, v. 32, n. 3, p. 591-601, 2012. https://doi.org/10.1590/S0100-69162012000300018

BECK, H. E.; VAN DIJK, A. I. J. M.; ROO, A.; MIRALLES, D. G.; MCVICAR, T. R.; SCHELLEKENS, J.; BRUIJNZEEL, A. Global-scale regionalization of hydrologic model parameters. Water Resources Research, v. 52, n. 5, p. 1-24, 2016. https://doi.org/10.1002/2015WR018247

BESKOW, S.; TIMM, L. C.; TAVARES, V. E. Q.; CALDEIRA, T. L.; AQUINO, L. S. Potential of the LASH model for water resources management in data-scarce basins: a case study of the Fragata River basin, southern Brazil. Hydrological Sciences Journal Journal Des Sciences Hydrologiques, v. 61, n. 14, p. 2567-2578, 2016. https://doi.org/10.1080/02626667.2015.1133912

CASSALHO, F.; BESKOW, S.; VARGAS, M. M.; MOURA, M. M.; ÁVILA, L. F.; MELLO, C. R. Hydrological regionalization of maximum stream flows using an approach based on L-moments. Revista Brasileira de Recursos Hídricos, v. 22, e27, p. 1-9, 2017. https://doi.org/10.1590/2318-0331.021720160064

CECÍlIO, R. A.; ZANETTI, S. S.; GASPARINI, K. A. C.; CATRINCK C. N. Avaliação de Métodos para Regionalização das Vazões Mínimas e Médias na Bacia do Rio Itapemirim. Scientia Agraria, v. 19, n. 2, p. 100-113, 2018.

ELETROBRAS. Metodologia para regionalização de vazões. Rio de Janeiro, 1985. p. 2025.

EPE. Estudos de Inventário Hidrelétrico da Bacia do Rio Juruena. Relatório Final, Avaliação Ambiental. EG223-GE-00-RF-001. São Paulo: CNEC, 2010. Vol. 25. p. 86.

IBGE. Área Territorial Brasileira. 2015. Available at: http://www.ibge.gov.br/home/geociencias/areaterritorial/principal.shtm Access: 28 May 2017.

LI, M.; SHAO, Q.; ZHANG, L.; CHIEW, F. H. S. A new regionalization approach and its application to predict flow duration curve in ungauged basins. Journal of Hydrology, $\mathrm{v}$. 389, p. 137-145, 2010. https://doi.org/10.1016/j.jhydrol.2010.05.039

LISBOA, L.; MOREIRA, M. C.; SILVA, D. D.; PRUSKI, F. F. Estimativa e Regionalização das vazões mínimas e médias da bacia do rio Paracatu. Engenharia na Agricultura, v. 16, n. 4, p. 471-479, 2008.

LOPES, T. R.; PRADO, G.; ZOLIN, C. A.; PAULINO, J.; ANTONIEL, L. S. Regionalização de Vazões Máximas e Mínimas para a Bacia do Rio Ivaí, PR. Irriga, v. 21, n. 1, p. 188201, 2016. https://doi.org/10.15809/irriga.2016v21n1p188-201 
LOPES, T. R.; ZOLIN, C. A.; PRADO, G.; PAULINO, J.; ALM14EIDA, F. T. Regionalization of maximum and minimum flow in the Teles Pires basin, Brazil. Engenharia Agrícola, v. 37, n. 1, p. 54-63, 2017. https://doi.org/10.1590/1809-4430-eng.agric.v37n1p54$63 / 2017$

LORENZON, A. S.; FRAGA, M. S.; MOREIRA, A. R.; ULIANA, E. M.; SILVA, D. D.; RIBEIRO, C. A. A. S.; BORGES, A. C. Influência das características morfométricas da bacia hidrográfica do rio Benevente nas enchentes no município de Alfredo Chaves-ES. Revista Ambiente \& Água, v. 10, n. 1, p. 195-206, 2015. https://doi.org/10.4136/ambiagua. 1475

MORIASI, D. N.; ARNOLD, J. G.; VAN LIEW, M. W.; BINGNER, R. L.; HARMEL, R. D.; VEITH, T. L. Model evaluation guidelines for systematic quantification of accuracy in watershed simulations. Transactions of the ASABE, v. 50, n. 3, p. 885-900, 2007.

NAGHETTINI, M. Fundamentals of Statistical Hydrology. Switzerland: Springer, 2016. 674 p.

OLIVEIRA, R. F.; ZOLIN, C. A.; VICTORIA, D. C.; LOPES, T. R.; VENDRUSCULO, L. G.; PAULINO, J. Hydrological calibration and validation of the MGB-IPH model for water resource management in the upper Teles Pires River basin in the Amazon-Cerrado ecotone in Brazil. Acta Amazônica, v. 49, n. 1, p. 54-63, 2019. https://doi.org/10.1590/1809-4392201800812

PRUSKI, F. F.; NUNES, A. A.; PRUSKI, P. L.; RODRIGUEZ, R. G. Improved regionalization of streamflow by use of the streamflow equivalent of precipitation as an explanatory variable. Journal of Hydrology, v. 476, p. 52-71, 2013. https://doi.org/10.1016/j.jhydrol.2012.10.005

PRUSKI, F. F.; RODRIGUEZ, R. D. G.; NUNES, A. A.; PRUSKI, P. L.; SINGH, V. P. Lowflow estimates in regions of extrapolation of the regionalization equations: a new concept. Engenharia Agrícola, v. 35, n. 5, p. 808-816, 2015. https://doi.org/10.1590/1809-4430Eng.Agric.v35n5p808-816/2015

PRUSKI, F. F.; SILVA, D. D.; KOETZ, M. Estudo de vazão em cursos d'água. Viçosa: AEAGRI, 2006. 151 p.

SOUZA, A. P.; MOTA, L. L.; ZAMADEI, T.; MARTIM C. C.; ALMEIDA, F. T.; PAULINO, J. Classificação climática e balanço hídrico climatológico no Estado de Mato Grosso. Nativa, v. 1, n. 1, p. 34-43, 2013.

TUCCI, C. E. M. Hidrologia: ciência e aplicação. 4. ed. Porto Alegre: Editora da UFRGS, 2009. $943 \mathrm{p}$.

TUCCI, C. E. M.; CLARKE, R. T. Regionalização Hidrológica. In: PAIVA, J. B. D.; PAIVA, E. M. C. D. Hidrologia Aplicada à Gestão de Pequenas Bacias Hidrográficas. Porto Alegre: ABRH, 2016. Cap. 7. p. 169-222.

ULIANA, E. M.; SOUZA, L. G. S.; SILVA, D. D.; SOUZA, A. P.; ALMEIDA, F. T.; ARAÚJO, H. B. Regionalização de vazões para o médio e alto rio Teles Pires - MT. Revista de Ciências Agrárias, v. 59, n. 4, p. 333-338, 2016.

VAN LIEW, M. W.; VEITH, T. L.; BOSCH, D. D.; ARNOLD, J. G. Suitability of SWAT for the conservation effects assessment project: a comparison on USDA-ARS watersheds. Journal of Hydrologic Engineering, v. 12, n. 2, p. 173-189, 2007. 
VILLELA, S. M.; MATTOS, A. Hidrologia aplicada. São Paulo: McGraw-Hill do Brasil, 1975.

WENZEL, D. A.; ULIANA, E. M.; ALMEIDA, F. T.; SOUZA, A. P.; MENDES, M. A. S. A.; SOUZA, L. G. S. Características fisiográficas de sub-bacias do Médio e Alto Rio Teles Pires, Mato Grosso. Revista de Ciências Agroambientais, v. 15, n. 2, p. 123-131, 2017. 